\title{
Pengaruh Hidroterapi dan Relaksasi Benson (Hidroson) terhadap Penurunan Tekanan Darah dan Nadi
}

\section{Effects of Hydrotherapy and Benson Relaxation (Hidroson) on Reducing Blood Pressure and Pulse}

\author{
Riska P. Meiyana ${ }^{1}$, Cornelia D. Y. Nekada ${ }^{1}$, Adi Sucipto ${ }^{1}$ \\ 1) Universitas Respati Yogyakarta, Jalan Raya Tajem Maguwoharjo, Depok, Sleman, Yogyakarta, 55281, Indonesia \\ Korespondensi: riskaputrimeiyana@gmail.com
}

Submitted: 4 Juni 2019, Revised: 20 Agustus 2019, Accepted: 26 Agustus 2019

https://doi.org/10.22435/jpppk.v3i2.2119

\begin{abstract}
Abstrak
Terapi komplementer merupakan salah satu alternatif untuk mengatasi masalah kesehatan. Hidroterapi dan relaksasi Benson merupakan terapi komplementer yang efektif terhadap tekanan darah dan nadi, namun masih jarang masyarakat yang memanfaatkannya. Diketahui ada pengaruh kombinasi hidroterapi dan relaksasi Benson (disebut hidroson) terhadap tekanan darah dan nadi. Metode penelitian pra-eksperimen, pre- and post- design dengan teknik purposive sampel pada 32 responden usia 26-65 tahun. Penelitian dilakukan dari tanggal 1-18 Maret 2019 di RT 19 dan 20, Sungapan V Desa Wahyuharjo, Kecamatan Lendah, Kabupaten Kulon Progo dengan tiap responden diberikan intervensi selama 3 hari berturut-turut. Instrumen yang digunakan adalah sphygmomanometer digital untuk mengukur tekanan darah dan nadi 5 menit sebelum dan sesudah pemberian terapi. Tekanan darah dianalisis dengan wilcoxon test dan paired $t$-test untuk nadi. Hasil analisis menunjukkan tekanan darah sistolik sebelum terapi sebesar $118,25 \mathrm{mmHg}$ dan setelah terapi sebesar 111,00 $\mathrm{mmHg}$, sehingga disimpulkan terjadi penurunan sebesar $7,25 \mathrm{mmHg}$ dengan $\rho$ Value 0,0001 . Tekanan darah diastolik sebelum terapi sebesar $81,25 \mathrm{mmHg}$ dan setelah terapi sebesar $78,75 \mathrm{mmHg}$, sehingga disimpulkan terjadi penurunan sebesar $2,50 \mathrm{mmHg}$ dengan $\rho$ value 0,002 . Nadi sebelum terapi sebesar $82,30 \mathrm{x} / \mathrm{menit}$ dan setelah terapi sebesar 80,64 $\mathrm{x} /$ menit, sehingga disimpulkan terjadi penurunan sebesar 1,66 x/menit dengan $\rho$ value 0,003 . Ada pengaruh yang signifikan terhadap pemberian kombinasi hidroterapi dan relaksasi Benson (hidroson) terhadap penurunan tekanan darah dan nadi di RT 19 dan 20, Sungapan V.
\end{abstract}

Kata kunci: hidroterapi, Relaksasi Benson, tekanan darah, nadi

\section{Abstract}

Complementary therapy is one alternative to solving health problems. Hydrotherapy and Benson's relaxation are effective complementary therapies for blood pressure and pulse, but still few patients utilize it. There is a known effect of hydrotherapy and Benson relaxation combination (called hydrosol) on blood pressure and pulse. The study method was pre-experimental with pre and post design with a purposive sampling technique on 32 respondents aged 26-65 years. The study was conducted from 1-18 March 2019 in neighborhood 19 and 20, Sungapan V, Wahyuharjo Village, Lendah District, Kulon Progo. Regency Each respondent was given intervention with hydrosol therapy for 3 consecutive days. The instrument used was a digital sphygmomanometer to measure blood pressure and pulse 5 minutes before and after the administration of therapy. Blood pressure was analyzed by the Wilcoxon test while pulsing by paired t-test. The analysis showed that systolic blood pressure before therapy was $118.25 \mathrm{mmHg}$ and after therapy became 111,00 $\mathrm{mmHg}$, so there was a decrease of $7,25 \mathrm{mmHg}$ with a $\mathrm{p}$-value of 0,0001 . The diastolic blood pressure before treatment was $81,25 \mathrm{mmHg}$ and after therapy became $78,75 \mathrm{mmHg}$, so there was a decrease of 2,50 mmHg with a p-value of 0,002 $\mathrm{mm}$. The pulse before therapy was 82,30 x/min and after therapy became 80,64 x/min, so there was a decrease of $1,66 \mathrm{x} / \mathrm{min}$ with $\rho$-value 0,003 . There is a significant effect of giving a combination of 
hydrotherapy and Benson relaxation (hydrosol) on reducing blood pressure and pulse among 32 subjects in neighborhood 19 and 20, Sungapan V.

\section{Keywords: hydrotherapy, Benson Relaxation, blood pressure, pulse}

\section{Pendahuluan}

Dewasa ini dunia kesehatan semakin berkembang pesat. Seiring dengan perkembangan dunia kesehatan banyak ilmuwan maupun tenaga kesehatan berlomba-lomba untuk mengembangkan dan/atau menemukan metode pengobatan baik konvensional maupun komplementer yang dapat digunakan untuk menyembuhkan pasien dan memajukan dunia kesehatan. Salah satu masalah yang sering ditemukan pada masyarakat Indonesia adalah hipertensi. Berdasarkan hasil studi literatur didapatkan bahwa prevalensi hipertensi di Indonesia berdasarkan diagnosis oleh tenaga kesehatan dan/ atau riwayat minum obat $7,8 \%$ atau hanya $24,2 \%$ dari kasus hipertensi di masyarakat. Berarti $75,8 \%$ kasus hipertensi di Indonesia belum terdiagnosis dan terjangkau pelayanan kesehatan. Menurut data Riskesdas 2007, prevalensi hipertensi di wilayah Yogyakarta mencapai 35,8\%. ${ }^{1}$

Dalam dua dekade terakhir banyak dilakukan penelitian terkait terapi komplementer di Eropa bahkan cenderung terus mengalami peningkatan. ${ }^{2}$ Di Canada sendiri semakin banyak orang yang menggunakan terapi komplementer yang merupakan bagian dari complementary and alternative medicine (CAM). ${ }^{3}$ Berbeda halnya dengan Canada dan negara lain, terapi komplementer masih jarang digunakan oleh masyarakat Indonesia. Dari 5 jenis terapi komplementer terdapat dua jenis terapi yang paling umum digunakan untuk mengobati penyakit hipertensi yaitu biologically-based dan mind-body therapies. Di Indonesia sendiri, penggunaan terapi komplementer banyak dilakukan sebagai salah satu terapi alternatif yang memiliki banyak keunggulan yaitu di antaranya selain harganya yang murah dan mudah dilakukan, juga terapi komplementer ini memiliki efek samping yang kecil atau bahkan sangat minimal untuk pengobatan. ${ }^{4}$

Terapi komplementer merupakan salah satu alternatif untuk mengatasi masalah kesehatan. Salah satu contoh dari biologically-based adalah hidroterapi. Hidroterapi merupakan istilah medis yang diadopsi untuk mendeskripsikan air sebagai media pengobatan. ${ }^{5}$ Pemberian hidroterapi efektifitas terhadap penurunan tekanan darah pada lansia penderita hipertensi di Panti Werda Al-Islah Malang. ${ }^{6}$ Berdasarkan studi literatur, diketahui bahwa tidak hanya hidroterapi yang memiliki pengaruh terhadap tekanan darah tetapi terapi relaksasi juga mampu memengaruhi tekanan darah dan nadi. Terapi relaksasi merupakan jenis terapi komplementer mind-body therapies yang masuk dalam kategori meditasi ${ }^{4}$ dan bermanfaat untuk menurunkan tekanan darah baik sistolik maupun diastolik pada penderita hipertensi. ${ }^{7}$ Hasil-hasil penelitian tersebut kemudian menjadi acuan untuk mencari terapi relaksasi yang dapat memengaruhi tekanan darah dan nadi. Salah satu terapi yang dapat memengaruhi tekanan darah dan nadi, yaitu relaksasi Benson. ${ }^{8}$ Relaksasi Benson merupakan kombinasi terapi relaksasi dengan faktor kepercayaan seseorang yaitu pengucapan kata atau kalimat sesuai kepercayaan yang dianut (berfokus pada nama Tuhan atau kata-kata berunsur keagamaan yang menenangkan) yang dilakukan berulang kali dengan teratur dan berserah pada Tuhan. ${ }^{9}$ Relaksasi Benson menyebabkan perubahan yang signifikan antara tekanan darah (baik sistolik maupun diastolik) dan nadi sebelum dan setelah diberikan intervensi. ${ }^{10}$

Hasil studi pendahuluan yang dilakukan peneliti pada tanggal 18 November 2018 di Pedukuhan Sungapan V, rukun tetangga (RT) 19 dan 20, rukun warga (RW) 10, Desa Wahyuharjo, Kecamatan Lendah, Kabupaten Kulon Progo, Daerah Istimewa Yogyakarta (DIY) mendapatkan hasil pengukuran tekanan darah dari 3 orang warga yaitu 138/101 mmHg, 113/68 $\mathrm{mmHg}$ dan 110/75 mmHg. Sedangkan untuk nadi yaitu $79 \mathrm{x} /$ menit, $88 \mathrm{x} /$ menit dan $79 \mathrm{x} /$ menit. Selain itu, berdasarkan hasil wawancara dengan ketiga responden diketahui bahwa masyarakat Pedukuhan Sungapan V khususnya RT 19 dan 20 belum pernah mendapatkan terapi kombinasi hidroterapi dan relaksasi Benson (hidroson) dan pernyataan tersebut juga didukung oleh kepala dukuh setempat. Adapun tujuan penelitian ini adalah untuk mengetahui pengaruh 
hidroson terhadap penurunan tekanan darah dan nadi di RT 19 dan 20, Sungapan V.

\section{Metode}

Desain penelitian ini menggunakan pre experimental pre and post test design dengan teknik purposive sampling. Penelitian ini dilakukan dari tanggal 1-18 Maret 2019. Responden pada penelitian ini adalah warga RT 19 dan 20 Sungapan V, Desa Wahyuharjo, Kecamatan Lendah, Kabupaten Kulon Progo. Sebanyak 32 responden memenuhi kriteria inklusi yaitu berdomisili tetap minimal 6 bulan terakhir sebelum penelitian dilakukan, berusia antara 26-65 tahun serta beragama Islam yang bersedia menjadi responden, tekanan darah di atas 90/69 mmHg serta dalam kondisi sehat saat penelitian berlangsung. Kriteria eksklusi adalah rutin mengonsumsi antihipertensi, salah satu atau kedua kaki diamputasi serta bedrest total. Responden yang bersedia dan memenuhi kriteria diminta menandatangani surat pernyataan kesediaan sebagai responden dan kemudian mendapat terapi hidroson selama 3 hari berturut-turut.

Hidroson dilakukan dengan cara merendam kaki menggunakan air hangat $\left(37-40^{\circ} \mathrm{C}\right)$ sambil responden melakukan napas dalam sebanyak 3 kali, ditahan sebentar dan dihembuskan sambil mengucap kata "Allah" kemudian dilakukan berulang kali selama 10 menit. Digital sphygmomanometer digunakan untuk mengukur tekanan darah dan nadi yang dilakukan oleh peneliti setiap hari selama intervensi, 5 menit sebelum dan sesudah intervensi selama 3 hari berturut-turut. Proses penelitian ini telah mendapat persetujuan etik dari komite etik penelitian Universitas Respati Yogyakarta (No.: 003.3/FIKES/PL/II/2019). Uji normalitas data tekanan darah sistolik, diastolik, dan nadi dilakukan dengan uji Saphiro-Wilk. Sehingga untuk tekanan darah dengan persebaran data tidak normal dianalisa menggunakan wilcoxon test sedangkan nadi yang persebaran datanya normal menggunakan paired t-test. Pada penelitian ini hipotesa diterima apabila $\rho$ value $<0,05$.

\section{Hasil \\ Karakteristik Responden}

Tabel 1 menunjukkan bahwa karakteristik usia responden pada penelitian ini lebih banyak pada kisaran $46-55$ tahun yaitu 11 orang $(34,4 \%)$ dan paling sedikit pada kisaran 26-35 tahun yaitu 5 orang $(15,6 \%)$. Sedangkan menurut jenis kelamin, responden pada penelitian ini lebih banyak lakilaki yaitu 17 orang $(53,1 \%)$ dibandingkan dengan perempuan yaitu 15 (46,9\%). Berdasarkan Tabel 1 juga diketahui bahwa mean tekanan darah sistolik, tekanan darah diastolik dan nadi sebelum intervensi paling tinggi berada pada rentang usia 36-45 tahun yaitu $123,67 / 84,39 \mathrm{mmHg}$ dan 86,11 $\mathrm{x} /$ menit. Sedangkan mean tekanan darah dan nadi berdasarkan jenis kelamin pada perempuan lebih tinggi dibandingkan dengan laki-laki yaitu $121,57 / 83,30 \mathrm{mmHg}$ dan $85,93 \mathrm{x} /$ menit.

Tabel 1. Distribusi Frekuensi Karakteristik Responden Berdasarkan Compare Mean Tekanan Darah dan Nadi dengan Usia dan Jenis Kelamin Responden di RT 19 dan 20, Sungapan V Maret 2019 $(\mathbf{n}=32)$

\begin{tabular}{llllll}
\hline & Frekuensi (f) & $\begin{array}{l}\text { Persentase } \\
(\mathbf{1 0 0 \%})\end{array}$ & $\begin{array}{l}\text { Mean Tekanan Darah } \\
\text { Sistolik (mmHg) }\end{array}$ & $\begin{array}{l}\text { Mean Tekanan Darah } \\
\text { Diastolik (mmHg) }\end{array}$ & $\begin{array}{l}\text { Mean Nadi (x/ } \\
\text { menit) }\end{array}$ \\
\hline Usia (Tahun) & & & & & \\
$56-65$ & 7 & 21,9 & 122,57 & 79,79 & 76,93 \\
$46-55$ & 11 & 34,4 & 119,50 & 82,41 & 82,32 \\
$36-45$ & 9 & 28,1 & 123,67 & 84,39 & 86,11 \\
$26-35$ & 5 & 15,6 & 116,90 & 82,50 & 86,10 \\
Jenis Kelamin & & & & & \\
Perempuan & 17 & 53,1 & 121,57 & 83,30 & 85,93 \\
Laki-laki & 15 & 46,9 & 120,38 & 81,62 & 80,03 \\
\hline
\end{tabular}




\section{Perubahan Tekanan Darah Sistolik dan Diastolik Pre Post Intervensi Hidroson}

Berdasarkan Tabel 2 perubahan tekanan darah sistolik dan diastolik pre post intervensi hidroson didapatkan selisih median $-7,25 \mathrm{mmHg}$ yaitu ada penurunan tekanan darah sistolik pre post intervensi hidroson dengan hasil $\rho$ value 0,0001 yang artinya ada perbedaan yang bermakna antara tekanan darah sistolik pre dan post intervensi hidroson. Hasil selisih median pada tekanan darah diastolik juga menunjukkan adanya penurunan yaitu
$-2,50 \mathrm{mmHg}$ dengan hasil $\rho$ value 0,002 yang artinya ada perbedaan yang bermakna antara tekanan darah diastolik pre dan post intervensi hidroson.

\section{Perubahan Nadi Pre Post Intervensi Hidroson}

Berdasarkan Tabel 3 perubahan nadi pre post intervensi hidroson didapatkan hasil selisih mean $-1,66 \mathrm{x} /$ menit yaitu ada penurunan nadi pre post intervensi hidroson dengan $\rho$ value 0,023 yang artinya ada perbedaan yang bermakna antara nadi pre dan post intervensi hidroson.

Tabel 2. Perubahan Tekanan Darah Sistolik dan Diastolik Pre Post Intervensi Hidroson di RT 19 dan 20, Sungapan V Maret 2019

\begin{tabular}{llll}
\hline Tekanan Darah & Median $(\mathbf{m m H g})$ & Selisih Median $(\mathbf{m m H g})$ & $\boldsymbol{\rho}$ Value \\
\hline Sistolik & & & \\
Pre & 118,25 & $-7,25$ & 0,0001 \\
Post & 111,00 & & \\
Diastolik & & & \\
Pre & 81,25 & $-2,50$ & 0,002 \\
Post & 78,75 & & \\
\hline
\end{tabular}

*Keterangan: - (negatif) menjelaskan adanya penurunan

Tabel 3. Perubahan Nadi Pre Post Intervensi Hidroson di RT 19 dan 20, Sungapan V Maret 2019

\begin{tabular}{llll}
\hline & Mean $(\mathbf{x} /$ menit) & Selisih Mean $(\mathbf{x} /$ menit) & $\boldsymbol{\rho}$ Value \\
\hline Nadi pre & 82,30 & $-1,66$ & 0,023 \\
Nadi post & 80,64 & & \\
\hline
\end{tabular}

*Keterangan: - (negatif) menjelaskan adanya penurunan

\section{Pembahasan}

Usia

Hasil penelitian ini menunjukkan bahwa semakin bertambahnya usia, tekanan darah sistolik cenderung mengalami peningkatan sedangkan pada tekanan darah diastolik dan nadi cenderung mengalami penurunan. Padahal menurut teori, semakin bertambahnya usia tekanan darah baik sistolik maupun diastolik cenderung mengalami peningkatan. Hal ini dikarenakan dengan adanya pertambahan usia maka elastisitas dinding arteri akan mengalami penurunan akibatnya tekanan darah sistolik dan diastolik cenderung mengalami peningkatan. ${ }^{11}$ Adanya penyempitan dan berkurangnya elastisitas dinding arteri tersebut berakibat pada peningkatan tekanan darah yang erat kaitannya dengan kejadian hipertensi. ${ }^{12}$ Namun pada penelitian ini hanya tekanan darah sistolik saja yang mengalami peningkatan seiring dengan bertambahnya usia.

Adapun penurunan tekanan darah diastolik yang terjadi seiring dengan bertambahnya usia pada penelitian ini tidak begitu signifikan. Penurunan tekanan darah diastolik pada penelitian ini mungkin terjadi akibat tahanan pada pembuluh darah tidak terjadi di sistem pembuluh peripheral. Karena apabila ada tahanan di peripheral maka akan berpotensi menyebabkan peningkatan tekanan darah terutama pada tekanan darah diastolik. ${ }^{11}$ Adanya peningkatan tahanan pembuluh darah berkaitan 
dengan pertambahan usia yaitu membantu dalam pemeliharaan perfusi koroner sehingga sebagai bentuk kompensasi tekanan darah diastolik akan mengalami penurunan karena adanya kekakuan arteri. ${ }^{13}$ Mungkin saja hal tersebut juga terjadi pada penelitian ini sehingga tekanan darah diastolik pada penelitian ini cenderung mengalami penurunan.

Sedangkan pada nadi, hasil penelitian ini menunjukan bahwa semakin bertambahnya usia terjadi penurunan pada tekanan nadi responden. Hasil penelitian tersebut sesuai dengan teori bahwa semakin bertambahnya usia maka nadi cederung mengalami penurunan. ${ }^{11}$ Semakin bertambahnya usia menyebabkan terjadinya perubahan pada struktur jantung dan fungsi jantung sehingga terjadinya penurunan fungsi pada sel sistem konduksi akibatnya mekanisme barorefleks mengalami gangguan berupa penurunan sensitivitas yang kemudian berakibat pada penurunan nadi. ${ }^{14}$

\section{Jenis Kelamin}

Berdasarkan hasil penelitian ini dapat disimpulkan bahwa baik tekanan darah maupun nadi pada perempuan cenderung lebih tinggi dibandingkan dengan laki-laki. Hal ini dikarenakan pada saat pubertas tekanan darah pada perempuan cenderung lebih rendah dibandingkan laki-laki namun ketika perempuan melewati fase menopause tekanan darah menjadi cenderung lebih tinggi dibandingkan laki-laki. ${ }^{11}$ Kecenderungan tingginya tekanan darah perempuan dikarenakan adanya beberapa mekanisme dalam tubuh seperti penurunan hormon estrogen pada perempuan postmenopause yang mengakibatkan terjadinya peningkatan tekanan darah. ${ }^{15}$ Namun perbedaan tekanan darah perempuan dan laki-laki pada penelitian ini tidak menunjukkan perbedaan yang signifikan. Hal tersebut sesuai dengan teori bahwa tidak ada perbedaan yang signifikan antara tekanan darah pada laki-laki maupun perempuan. ${ }^{12}$

Berdasarkan klasifikasi tekanan darah dewasa menurut JNC 8 dapat disimpulkan bahwa rata-rata tekanan darah responden baik perempuan maupun laki-laki pada penelitian ini masuk dalam kategori prehipertensi. Menurut klasifikasi tekanan darah menurut JNC 8, tekanan darah seseorang masuk kategori prehipertensi apabila tekanan darah sistolik berada di rentang $120-140 \mathrm{mmHg}$ dan tekanan darah diastolik berada di rentang 80$90 \mathrm{mmHg} .{ }^{16}$ Sedangkan bila dilihat dari mean nadi pada penelitian ini maka mean nadi perempuan lebih tinggi dibandingkan laki-laki. Hal tersebut karena setelah masa pubertas nadi pada laki-laki akan cenderung lebih rendah dibandingkan perempuan. ${ }^{11}$ Selain itu, berdasarkan mean nadi responden perempuan maupun laki-laki maka pada penelitian ini nilai nadi masuk ke klasifikasi normal. Nilai nadi normal pada dewasa yaitu $70 \mathrm{x} /$ menit atau berada pada kisaran $60-100 \mathrm{x} /$ menit. $^{16}$

\section{Perubahan Tekanan Darah Sistolik dan Diastolik Pre Post Intervensi Hidroson}

Hasil penelitian ini menunjukkan bahwa ada perubahan yang bermakna antara tekanan darah sistolik dan diastolik pre post intervensi hidroson dengan $\rho$ value secara berturut-turut 0,0001 dan 0,002. Rata-rata perubahan tekanan darah baik sistolik maupun diastolik secara berturut-turut setelah 7 hari intervensi berkisar $16,25 \mathrm{mmHg}$ dan $6,25 \mathrm{mmHg}^{17}$ sedangkan pada penelitian ini rata-rata penurunan tekanan darah sistolik dan diastolik yaitu $7,25 \mathrm{mmHg}$ dan $2,5 \mathrm{mmHg}$. Ada penurunan baik pada tekanan darah sistolik maupun diastolik post intervensi hidroson. Pada penelitian ini, penggunaan air hangat dalam durasi singkat menyebabkan organ pada sistem endokrin menjadi berkurang aktivitasnya, terutama kelenjar adrenal, sehingga menyebabkan terjadinya penurunan tekanan darah. ${ }^{18}$

Hal ini dikarenakan rendam kaki air hangat yang dilakukan bermanfaat untuk melancarkan aliran darah dan menyebabkan terjadinya pelebaran pembuluh darah. Dengan terjadinya aliran darah lancar dan pelebaran pembuluh darah maka berdampak pada penurunan tekanan darah. ${ }^{19}$ Penurunan tekanan darah tersebut juga dapat terjadi karena rendam kaki air hangat yang dilakukan rutin akan menghasilkan energi kalor yang bersifat mendilatasi dan melancarkan peredaran darah serta merangsang pengaktifan saraf parasimpatis pada kaki sehingga terjadi perubahan tekanan darah. ${ }^{20}$

Hal ini dikarenakan saat proses inspirasi panjang yang dilakukan pada saat relaksasi akan menstimulus secara perlahan-lahan reseptor regang paru-paru oleh adanya inflam si paru yang berakibat adanya rangsangan ke medulla yang memberikan informasi tentang peningkatan aliran darah. 
Informasi tadi akan diteruskan ke batang otak yang akan menyebabkan saraf parasimpatik mengalami penurunan aktivitas pada kemoreseptor. Penurunan aktivitas kemoreseptor tadi berakibat pada respons akut peningkatan tekanan darah dan inflamasi paru yang kemudian menurunkan frekuensi denyut jantung sehingga terjadi vasodilatasi pada sejumlah pembuluh darah. Pada keadaan tersebut, axis Hipothalamus-Pituitary-Adrenal (HPA) akan menurunkan kadar kortisol, epineprin dan norepineprin yang dapat menurunkan tekanan darah dan frekuensi nadi. Penurunan kadar kortisol darah akan menyebabkan vasokontriksi pembuluh darah sedangkan penurunan kadar epineprin dan norepineprin menyebabkan vasodilatasi pembuluh darah yang kemudian akan menurunkan tahanan perifer total yang berakibat menurunkan tekanan darah. ${ }^{21}$

Penurunan aktivitas fisik yang terjadi selama intervensi juga berpengaruh pada perubahan tekanan darah. Pada saat terjadi penurunan aktivitas fisik, aktivitas memompa di jantung menjadi lemah. Melemahnya aktivitas memompa di jantung menyebabkan hanya sedikit darah yang dapat dipompa ke pembuluh darah dan mengakibatkan terjadinya penurunan cardiac output. Adanya penurunan cardiac output tersebut akan menyebabkan tekanan darah menurun. ${ }^{11}$

\section{Perubahan Nadi Pre Post Intervensi Hidroson}

Hasil penelitian ini menunjukkan bahwa ada perbedaan yang signifikan antara nadi pre dan post intervensi hidroson dengan hasil $\rho$ value 0,023 . Sebelum diberikan intervensi rata-rata nadi responden $82,80 \mathrm{x} /$ menit dan setelah diberikan intervensi selama 3 hari berturut-turut menjadi $80,64 \mathrm{x} /$ menit atau dengan kata lain terjadi penurunan sebanyak $1,66 \mathrm{x} /$ menit. Penurunan nadi pada teknik relaksasi Benson dan hidroterapi karena sensasi rileks yang dihasilkan. Relaksasi Benson akan menyebabkan saraf parasimpatik tetap aktif dan saraf simpatik mengalami penurunan aktivitas. ${ }^{10}$ Hidroterapi sendiri akan menghasilkan energi yang nantinya bertugas untuk mendilatasi dan melancarkan peredaran darah serta merangsang pengaktifan saraf parasimpatik pada kaki. Adanya pengaktifan saraf parasimpatik pada kedua terapi tersebut menyebabkan terjadinya penurunan nadi. ${ }^{20}$
Selain itu, adanya penurunan tekanan darah karena penurunan aktivitas pompa jantung juga berpengaruh terhadap penurunan nadi. Hal ini dikarenakan nadi merupakan jumlah kali per menit jantung terisi oleh darah dan kemudian darah tersebut dipompakan ke seluruh sistem pembuluh darah ${ }^{22}$ sehingga apabila terjadi penurunan tekanan darah akibat penurunan aktivitas pompa jantung maka akan berimbas juga pada penurunan nadi.

\section{Kesimpulan}

Ada pengaruh yang signifikan dari kombinasi hidroterapi dan relaksasi Benson (hidroson) terhadap penurunan tekanan darah (sistolik dan diastolik) dan nadi pada responden di rukun tetangga 19 dan 20, Sungapan V. Penelitian ini merupakan penelitian awal (preliminary research) sehingga secara telaah ilmiah maupun referensi penelitian ini belum menemukan kapan dan berapa kali pemberian intervensi hidroson yang efektif.

\section{Saran}

Hidroson dapat diberikan secara rutin sebagai terapi alternatif maupun intervensi keperawatan untuk menurunkan tekanan darah dan nadi. Perlu adanya penelitian lanjutan terkait waktu dan frekuensi yang efektif untuk terapi hidroson pada pasien hipertensi maupun untuk meneliti pada variabel terkait lainnya.

\section{Ucapan Terima Kasih}

Terima kasih kepada Bapak Triyanto selaku kepala Pedukuhan Sungapan V dan seluruh responden yang telah bersedia membantu penelitian ini. Tak lupa juga ucapan terima kasih kepada seluruh pihak yang telah membantu penelitian ini baik secara moril maupun materiil.

\section{Daftar Rujukan}

1. Kementerian Kesehatan RI. Penyakit tidak menular dalam: Laporan Nasional Riset Kesehatan Dasar 2018 [Internet]. Jakarta: Lembaga Penerbit Badan Penelitian dan Pengembangan Kesehatan; 2019 [diakses pada 5 Maret 2020]. p. 152-63. Tersedia pada: http:// labdata.litbang.depkes.go.id/images/download/ laporan/RKD/2018/Laporan_Nasional_ RKD2018_FINAL.pdf 
2. Fischer FH, Lewith G, Witt CM, Linde K, Ammon $\mathrm{K}$ von, Cardini F, et al. High prevalence but limited evidence in complementary and alternative medicine: Guidelines for future research. BMC Complement Altern Med [Internet]. 2014 [diakses pada 11 November 2018];14(46):1-9. Tersedia pada: https://www. ncbi.nlm.nih.gov/pmc/articles/PMC3931324/ pdf/1472-6882-14-46.pdf

3. Canizares M, Hogg-Johnson S, Gignac MAM, Glazier RH, Badley EM. Changes in the use practitioner-based complementary and alternative medicine over time in Canada: Cohort and Period Effects . PLoS One [Internet]. 2017 [diakses pada 26 Oktober 2018];12(5):117. Tersedia pada: https://journals.plos.org/ plosone/article/file?id=10.1371/journal. pone. $0177307 \&$ type $=$ printable

4. Rabito MJ, Kaye AD. Complementary and alternative medicine and cardiovascular disease: An evidence-based review. EvidenceBased Complement Altern Med [Internet]. 2013 [diakses pada 26 Oktober 2018];2013:1-8. Tersedia pada: https://www.ncbi.nlm.nih.gov/ pmc/articles/PMC3654705/pdf/ECAM2013672097.pdf

5. Moufarrij S, Deghayli L, Raffoul W, Hirt-Burri N, Michetti M, de Buys Roessingh A, et al. How important is hydrotherapy? Effects of dynamic action of hot spring water as a rehabilitative treatment for burn patients in Switzerland. Annals of Burns and Fire Disasters [Internet]. 2014 [diakses pada 26 Oktober 2018];27(4):184-91. Tersedia pada: https://www.ncbi.nlm.nih.gov/ pmc/articles/PMC4544428/pdf/Ann-Burnsand-Fire-Disasters-27-184.pdf

6. Dilianti IE, Candrawati E, Adi RC. Efektivitas hidroterapi terhadap penurunan tekanan darah pada lansia penderita hipertensi di Panti Werda Al-Islah Malang. Nurs News (Meriden) [Internet]. 2017 [diakses pada 26 Oktober 2018];2(3):193-206. Tersedia pada: https:// publikasi.unitri.ac.id/index.php/fikes/article/ view/579

7. Sulistyarini I. Terapi relaksasi untuk menurunkan tekanan darah dan meningkatkan kualitas hidup penderita hipertensi. J Psikol [Internet]. 2013 [diakses pada 11 November 2018];40(1):28-38.
Tersedia pada: https://jurnal.ugm.ac.id/jpsi/ article/view/7064/pdf_31

8. Nasiri M, Fayazi S, Karimvand HK. The effect of reciting the word "Allah" on vital signs and $\mathrm{SpO} 2$ of patients after coronary artery bypass Graft Surgery: A randomized clinical trial. Jundishapur J Chronic Dis Care [Internet]. 20 Apr 2015 [diakses pada 26 Oktober 2018];4(2):1-7. Tersedia pada: https://www. iosrjournals.org/iosr-jnhs/papers/vol6-issue5/ Version-9/K0605097987.pdf

9. Solehati T, Rustina Y. Benson relaxation technique in reducing pain intensity in women after cesarean section. Anesthesiol Pain Med [Internet]. 22 Jun 2015 [diakses pada 26 Oktober 2018];5(3):1-5. Tersedia pada: https://www. ncbi.nlm.nih.gov/pmc/articles/PMC4493735/ pdf/aapm-05-03-22236.pdf

10. Tahmasbi H, Hasani S. Effect of Benson's relaxation technique on the anxiety of patients undergoing coronary angiography: A randomized control trial. J Nurs Midwifery Sci [Internet]. 2016 [diakses pada 28 Oktober 2018];3(1):8-14. Tersedia pada: http://jnms. mazums.ac.ir/article-1-179-en.pdf

11. Berman A, Snyder S, Frandsen G. Kozier \& Erb's fundamentals of nursing concepts, process and practice. Edisi ke-10. Boston: Pearson; 2016.

12. Potter PA, Perry AG, Stockert PA, Hall AM. Fundamental of nursing. Edisi ke-9. Philadelphia: Elsevier Saunders; 2017. p. 486556.

13. Maksuti E, Westerhof N, Westerholf BE, Broome M, Stergiopulos N. Contribution of the arterial system and the heart to blood pressure during normal aging - A simulation study. PLoS One [Internet]. 2016 [diakses pada 10 November 2018];11(6):e0157493. Tersedia pada: https://journals.plos.org/ plosone/article/file?id=10.1371/journal. pone. $0157493 \&$ type $=$ printable

14. Hinkle JL, Cheever KH. Brunner and Suddarth's textbook of medical-surgical nursing. Edisi ke-14. Philadelphia: Wolters Kluwer; 2018. p. 927-929.

15. Shirani S, Gharipour M, Khosravi A, Kelishadi R, Habibi HR, Abdalvand A, et al. Gender 
differencesin the prevalence of hypertension in a representative sample of Iranian population: The Isfahan healthy heart program [Abstrak]. Acta Biomed [Internet]. 2011 [diakses pada 28 Februari 2019];82:223-9.Tersedia pada: https:// www.ncbi.nlm.nih.gov/pubmed/22783719

16. Cikulin-Kulinski K. Physical therapy clinical handbook for PTAs. Edisi ke-3. Burlington: Jones \& Bartlett Learning; 2018.

17. Sari LM, Ardila N. Pengaruh teknik kombinasi hidroterapi rendam hangat dan terapi relaksasi Benson terhadap penurunan tekanan darah pada pasien hipertensi di Puskesmas Maek Kecamatan Bukik Barisan. J Kesehat Perintis (Perintis' Health Journal) [Internet]. 2015 [diakses pada 10 November 2018];2(4):905. Tersedia pada: https://media.neliti.com/ media/publications/275147-pengaruh-teknikkombinasi-hidroterapi-re-818f85c3.pdf

18. Bahadorfar M. A study of hydrotherapy and it's health benefits. Int J Res [Internet]. 2014 [diakses pada 11 November 2018];1(8):294-305. Tersedia pada: https://journals.pen2print.org/ index.php/ijr/article/view/507

19. Ferayanti NM, Erwanto R, Sucipto A. The effectiveness Of warm water therapy and deep breathing relaxation in blood pressure. Nurscope J Penelit dan Pemikir Ilm Keperawatan [Internet]. 2017 [diakses pada 11 November 2018];3(2):38-45. Tersedia pada: http://jurnal.unissula.ac.id/index.php/jnm/ article/view/2317/1737

20. Harnani Y, Axmalia A. Terapi rendam kaki menggunakan air hangat efektif menurunkan tekanan darah pada lanjut usia. KESKOM [Internet]. 2017 [diakses pada 11 November 2018];3(4):129-32. Tersedia pada: http:// jurnal.htp.ac.id/index.php/keskom/article/ download/127/119/

21. Salafudin, Handayani S. Pengaruh teknik relaksasi benson terhadap tekanan darah pada lansia penderita hipertensi di posyandu lansia Larasati Dusun Wiyoro Bauretno Banguntapan Bantul Yogyakarta 2015. J Kesehat Samodra Ilmu [Internet]. 2015 [diakses pada 11 November 2018];06(02):150-9. Tersedia pada: http://id. portalgaruda.org/?ref=browse \&mod=viewarticle\&article $=413681$

22. Bedworth DA, Bedworth AE. Dictionary of health education. Oxford: Oxford University Press; 2010. 